\title{
A Study of the Poverty Alleviation Communication Practices of the German Agro Action in Gokwe South Rural District of Zimbabwe
}

\author{
Collet Tasaranago \\ Department of Communication \\ University of Fort Hare, Alice, South Africa \\ Professor Abiodun Salawu \\ Department of Communication, North-West University \\ Mafikeng Campus, South Africa
}

Doi:10.5901/mjss.2013.v4n13p581

\begin{abstract}
The study examined communication practices by Deutsche Weltihungerhilfe German Agro Action (GAA) in its poverty alleviation programmes in Gokwe South Rural District. The research identified the modes of communication and the languages used by GAA in its poverty alleviation programmes. The study was also interested in the messages communicated by GAA to the community. Both quantitative and qualitative methodologies were applied to assess the communication practices of GAA. The findings of the study revealed that the organisation used mainly the indigenous modes of communication. Modern modes of communication were used but to a lesser extent. The study also uncovered the challenges which inhibited the optimum usage of the communication modes for development purposes in the district. These include political and infrastructural challenges.
\end{abstract}

Keywords: Poverty Alleviation, Development Communication, Participation, Indigenous Communication Systems (ICSs), Modern Communication Systems (MCSs)

\section{Introduction}

Communication remains at the centre of every poverty alleviation activity by NGOs in rural areas. The successes of poverty alleviation activities are undoubtedly dependent on how well the process of communication is executed. Several international organisational summits have placed much emphasis on the importance of communication in the development of developing nations (FAO, 2012). Paradigms which trace the transition of the process of development communication since the colonial era clearly allude to the fact that it is imperative to take into consideration the modes of communication, the context and languages used (Melkote 2001, Salawu, 2004a). Modes and languages used in communication should be culture sensitive and contextualised to suit the interests and the situations of rural areas in the developing world. According to FAO, (2012) a number of poverty alleviation projects, especially by NGOs, have yielded little or no results at all. Research must therefore question the communication approach and possibly provide recommendations on the best ways of implementing the communication strategies to ensure that poverty alleviation projects become successful. In line with this, the successful communication of messages by NGOS can yield the intended objectives of poverty alleviation programmes. This paper sought to identify, evaluate and analyse the modes of communication employed by GAA in Gokwe South Rural District.

\section{Background to the Study}

NGOs' operations date back to the $19^{\text {th }}$ century when they focused on charitable work and philanthropy (Korten, 1986). Traditional structures have failed to meet the social needs of their societies thereby necessitating the growing importance of NGOs to fill in the gap. NGOs are seen as a response to the collapsing traditional structures and poverty has become one of the major concerns of NGOs in developing countries around the world. To this end, the world has seen an increase in the number of NGOs dealing with matters of development, poverty included. While it remains uncertain as to why after many years of NGOs operation, poverty is still a problem, it becomes imperative to study the communication 
component in NGOS' poverty alleviation programmes. Importantly, NGOs operate across the globe with pronounced activities in the developing nations. In this research, much focus was placed on NGOs' communication practices in Zimbabwe. There are about 2000 NGOs operating in Zimbabwe presently and GAA is among them (NANGO, 2006). This paper particularly focused on GAA in Gokwe South Rural District.

The use of communication as a vehicle of development communication activities have been hailed, as alluded to in several international orgnaisations summits (FAO, 2012). Communication is regarded as key to the success of development activities in third world countries. NGOs assumed the key role of change agencies to relieve nations and communities faced with various challenges. Key among these challenges has been poverty. In Zimbabwe GAA is among the NGOs trying to address the social malaise. Taking into the consideration that communication is hailed as crucial in each and every development programme, GAA's communication practices are put under the scrutiny. This paper discusses the modes and languages employed by GAA in communicating poverty alleviation programmes to the people of Gokwe South Rural District, Midlands, Zimbabwe.

\section{Gokwe South Rural District and Poverty}

Poverty is worst in rural areas. In Zimbabwe, about two thirds of the total population is living in rural areas. According to the Rural Poverty Portal (RPP) (2010), Zimbabwe has a total population of about 12522784 and a rural population of 7786667 which is $62 \%$ of the total population.

Gokwe South District has a population of 294627 people (James, 2006). Gokwe is mostly rural and most people depend on subsistence farming for a living. People grow mainly cotton as a cash crop and maize for both consumption and selling. Other crops grown are rapoko, sorghum, millet, round nuts and ground nuts. People also keep a small herd of cattle of about 5 to 8 due to lack of grazing land. Goats are also kept in these areas. A few farmers also keep sheep and pigs. In case of urgent need of cash, these farmers can sell their livestock. Those who own livestock are regarded as the wealthiest since many of the people do not own livestock. This forms the base of the agronomy of Gokwe.

Before the colonial era, the area was sparsely populated with only the Shangwe (a Shona tribe) people in the Zambezi valley. This was because of the unfavourable temperatures as well as the fact that the area was tsetse infested (James, 2006). Malaria was also an influential factor in inhibiting the settlement of people in the area. However, due to colonial oppressive rules in other provinces countrywide, people began to migrate into the area.

The natives were expelled from the Highveld after the Second World War and they resettled in Gokwe (Ranger, 1985, Worby, 2000). The elimination of tsetse later on also allowed the settling of people in the area. Part of the district lies on the Mapfungautsi plateau and the other part in the Zambezi valley. Due to severe changes in the climate, the political dynamics, historical injustices and economic strains, Gokwe South District has had difficulties in making sure that there is availability of food. Most of the populace is living in poverty.

This has seen various Non-Governmental Organisations (NGOs) like Care Africa, Concern, GAA and others trying to bring relief to the strained district of Gokwe. The issues addressed are food and nutrition, health issues, HIVIAids, clean water and agricultural productivity. GAA is amongst these NGOs trying to bring relief in Gokwe South Rural District (GSRD).

\section{Objectives of the Study}

The main objective of the study was to analyse the communication practices by Deutsche Weltihungerhilfe German Agro Action (GAA) in its poverty alleviation programmes in Gokwe South Rural District.

Specific objectives:

1. To find out the communication mediums and modes used by German Agro Action, a Non-Governmental Organisation, in conducting its programmes in Gokwe South Rural District.

2. To evaluate the effectiveness of the communication strategies used by GAA as well as the feedback system in poverty alleviation.

3. To identify the issues/themes communicated by GAA in its poverty alleviation programmes.

4. To determine the involvement of the rural people in the development communication process.

\section{Methodology}

This study employed a mixed method approach which involves the use of both qualitative and quantitative research 
methods. The use of both methods is advantageous considering that the combination of both approaches can offset the weaknesses of either approach when used alone (Creswell, 2003). According to Tashakkori and Teddlie (1998), both methods provide a comprehensive evidence for studying a research problem than when used separately. Mixing the research methods further encourages researchers to collaborate across the sometimes adversarial relationship between quantitative and quantitative researches (Creswell, 1999, 2003). Combining the research methods is practical because researchers use both numbers and words to solve problems. In addition, mixed methods combine both inductive and deductive thinking (Creswell, 2003). Hughs (1997) is of the opinion that quantitative approaches are associated with objectivity and qualitative approaches are associated with subjectivity. When both methods are used, subjective limitations of the accuracy of research can be overcome to yield objective findings. Qualitative and quantitative methods were used to supplement each other in an attempt to complement their strengths in terms of breadth and depth. In this study which was about communication practices, qualitative research had to be employed.

\subsection{Method of data collection}

Qualitative data were collected through in-depth semi-structured interviews. In this research, the interviewees were the GAA Project Manager, councillors and village heads. The in-depth semi-structured interview schedule was guided by prepared questions and the researcher asked further questions from the interviewees. The semi-structured interviews were informal and this allowed the interviewer to explore several aspects of the issues in depth by asking open questions which were designed to invite explanatory or detailed answers (Currie, 2005). Such a benefit of semi-structured interviews led the researchers to make use of the technique.

Semi-structured interviews are more flexible and allow the pursuit of unexpected lines of enquiry during the interview (Grix, 2001). In the present research a semi-structured method was employed to try and answer the research questions in order to find out the communication methods and practices used by the GAA as well as their effectiveness.

The researcher also used a self-administered questionnaire to collect quantitative data. In a survey, questionnaires are the most effective method when used in conjunction with other methods (Grix. 2001).

According to Kumar (1999) cited in Grix (2001) questions must be clear, unambiguous, and easy to understand. This assists the respondents to respond appropriately and uniformly to yield reliable results. A questionnaire method gives the respondents an opportunity to respond freely without the interference of the researcher unlike in interviews. According to Grix (2001), a careful consideration has to be made to ascertain that the questions in the questionnaire are clear and precise in relation to the idea being studied.

In the present study, respondents were the sample drawn from the population which was 120 family heads. The researchers also made use of research assistants to distribute the questionnaire copies. Respondents completed the questionnaire with the assistance of the researchers or research assistants. In-depth semi-structured interviews and the questionnaire were the two instruments used to collect qualitative and quantitative data in this research.

\subsection{Method of data analysis}

Data analysis is the process of gathering, modelling and transforming data with the goal of highlighting useful information, suggesting conclusions, and supporting decision making (Wellman .et.al, 2005). Data collected were analysed using the descriptive and inferential statistics by computer software known as Statistical Package for Social Sciences (SPSS). Descriptive statistics were used because they summarise data. Measures included averages, mean and mode. Inferential statistics were used because they help to reach conclusions by inferring from the data. They had an advantage in the study because they allowed judgments of probability from the observed differences between groups. The t-test was used to compare averages of performance between groups. To test the relationship among variables, the chi-square tests were employed.

Qualitative data were analysed using the grounded theory. The researcher read the data transcribed during the interviews and developed themes and patterns, classifying information according to the research objectives.

The Grounded theory provided insights into the communication strategies, their effectiveness, the conditions of their effectiveness and the effectiveness of the feedback system in GSRD by GAA. The method also involved the development of theories from the collected data (Strauss and Corbin, 1990, 1998). From the data, abstract concepts are developed. A concept is a core term in a theory. It summarises an important aspect of a problem under study and it is useful in collecting and interpreting evidence (McQuail, 2010). According to Strauss and Corbin (1998), the researcher must be close to the respondents in data collection. In this research, data were collected through semi-structured 
interviews with the village heads, the councillors, and the GAA Project Manager.

\section{Findings}

This section of the paper presents the findings from both quantitative and qualitative studies. 111 people out of a sample of 120 responded to a questionnaire. The gender distribution was almost equal with across the sample with 63 males and 48 females. Qualitative data was analysed using the Grounded theory.

\subsection{Modes of communication and languages used by GAA for its poverty alleviation programmes in Gokwe South Rural District (GRSD)}

The research revealed that GAA used mainly the Indigenous Communication Systems (ICSs), especially in communicating with the locals. $90 \%$ reported to have first heard about GAA through meetings. $85.6 \%$ of respondents reported that GAA used face-to-face communication to announce meetings which were attended by more than $90 \%$ of the respondents. Interviewees also agreed that people respected and attended the meetings. $38.7 \%$ reported that they asked questions by themselves from GAA and $30.6 \%$ reported that they would send someone. These are face to face communication methods which fall under ICSs. 78 out of 111 respondents reported that they lived close enough to GAA officials therefore face to face communication was likely to be effective.

95 out of the 111 respondents (85.6\%) reported that GAA personnel use face-to-face communication as a means of announcing meetings, while $6.3 \%$ reported the use of telephone, and $3.6 \%$ reported the use of posters and leaflets. GAA does not use the television, newspaper or magazines to call for meetings. Basically, GAA mainly used face-to-face and meetings. The respondents reported that GAA did not use any of the three modes of communication: magazines, newspapers and television. Both face-to-face and meetings (t-value $=7.217, p$-value $=.000$ ) and meetings (t-value $=3.724$, $p$-value $=.000)$ had significantly higher values than the bench-mark. A means comparison between the two variables showed that the respondents reported a significantly higher [t-value $=7.015, \mathrm{p}$-value $=.000,95 \% \mathrm{Cl}=(.756,1.352)]$ usage of the face-to-face medium as compared to the use of meetings.

The research also found out that the organisation used the Modern Communication Systems (MCSs) but to a lesser extent. These were in the form of cell phones and letters to communicate with the locals and other stakeholders. Using top down communication and bottom up communication the organisation communicated with the local people who were the partners in the programmes and other stakeholders. Many researchers agree that interpersonal face-to-face communication is effective. Face-to-face communication eliminates noise and chances of message distortion and it is understandable. It is also capable of changing attitudes since the speaker will be closer to the recipients of the messages. The method has great potential of informing and allows an opportunity for immediate feedback.

GAA personnel were reported to use only two languages; predominantly Shona (85\%) and Ndebele (15\%). These are the local languages which are understood by most of the locals. 95.5\% confirmed that they understood the language used. Significant associations between comprehension of the language of communication between the community and GAA officials and how long the community had known GAA (Chi-square=5.131, p-value=, 024) and gender (Chisquare $=6.872$, $p$-value $=.009$ ) were observed. More to that, it was also discovered that the organisation was flexible in the use of all the languages which the locals understood. While Nenty (1999) is of the view that other researchers' opinions are crucial in the discussion of the findings, arguments which support the use of local languages, their richness in getting the people to support certain ideas and opinions and to participate in the process of communication were also considered.

According to UNESCO (2012), language is the key to inclusion. When communication is done in the local language, people feel included and are inclined to identify with the ideas proposed. It is argued that language is at the centre of human activity, self-expression and identity (UNESCO 2012). Communicating with the people in their own language means recognising the primary importance that people place on their own language and that fosters the kind of true participation in development that achieves lasting results (UNESCO, 2012, Salawu 2004c).

Genuine participation, it is argued (UNESCO, 2012), relies on a two-way communication which means engaging with the languages people actually speak. Findings show that GAA was communicating using the local languages and the locals confirmed that they understood the messages well. According to Mozammel and Odugbemi (2005), language has a very influential role in fostering the process of an informed public dialogue and debate. Anyaemgbunam etal (2004) are of the view that the use of a variety of communication media ensures that information; skills and knowledge are available to the rural people. In this light, interpersonal face-to-face or written communication must be done in the local 
language in poverty alleviation communication in rural areas.

\subsection{Issues contained in the messages disseminated by GAA to the people of GSRD on poverty alleviation}

The research found out that GAA communicated messages concerned with the projects which it was running with the locals. One hundred percent of the respondents reported that GAA projects focused on crop production as well as health. Programmes concerned with clean water and environmental protection were reported second with $99.1 \%$ each while programmes concerned with livestock production were reported by $88.3 \%$ of the respondents. Education and training and family planning programmes were recorded least with $47.7 \%$ and $20.7 \%$ respectively. As a result, messages were considered informative. The programmes, just like any development initiative, are often new to the locals (FAO, 2000). This means that such innovations must be adopted by the locals so as to be able to realise poverty alleviation (Rogers, 2005). ICSs have been effectively used but the integration of these with the MCSs can facilitate the fast dissemination of messages.

It is unfortunate that it is complicated for GAA to effectively use the modern communication system for poverty alleviation initiatives in GSRD. The limitations are the inaccessibility of the available MCSs which are close to GAA and the GSRD which GAA can use for communication. The restrictive laws like AIPPA and POSA gag the freedom of communication thereby making the use of media a no-go-area for NGOs which may be having positive intentions. This has, however, rendered the MCSs in the state virtually poor and weak to be used for poverty alleviation communication. It is difficult for diffusion of innovations to happen using the MCSs.

\subsection{Involvement of the people in the GAA's communication process and effectiveness of the feedback system}

Despite the limited and restricted platforms of communication, the people in the district were involved in the communication process. This is reflected through the use of interpersonal methods of communication which are mainly meetings and face-to-face. The Relay communication technique by GAA is also considered crucial. Field Technicians (FTs) and the lead Farmers (LFs) are from the communities. In this manner the locals are involved in the communication process and there is opportunity for immediate feedback to take place. This form of involvement is participatory and made it easier even for the locals to also communicate with the organisation. Anyaemgbunam etal (2004) are of the opinion that lack of participation is one of the factors which slows down human development, the involvement of the people in GSRD was therefore flagged.

Locals were comfortable interacting and raising their concerns with the people who they are used to. FTs and LFs also were also empowered by the roles which were given to them. This form of involvement is applauded and encouraged in development and poverty alleviation programmes (De Beer \& Swannepoel, 1998, Anyaemgbunam etal, 2004).

The locals also participated during events and gatherings by performing in music, dance and drama. This manner of communication in oral arts and theatre is effective in development communication (Manyozo 2008, Salawu, 2004a, 2004b and Melkote, 2001). This form of involvement is healthy in poverty alleviation. It informed non-participants about the benefits of doing poverty alleviation programmes with GAA and it also encouraged participants to continue working hard. These forms of indigenous communication appealed to the emotions and changed the negative attitudes of the people towards GAA and its programmes while at the same time entertaining.

Furthermore, through the use of the indigenous forms of communication, participation has been registered through the communication activities by GAA in GSRD. There was an effective use of the involvement technique and it ensured that the locals owned the projects. According to FAO (2000), any development programme that regards people as mere recipients, rather than as the actual creators of change and progress, usually fails. Anyaemgbunam etal (2004) also says that when the locals are actively involved in communication during all stages of projects, the projects will address their real needs and arising problems will be identified. As a result, programme adjustments or re-packaging can be done so that they will be successful. Importantly, there is a general consensus between the people and the change agents. The findings of this study noted an active involvement of people during the programmes (programme implementation stage) which were designed by the organisation. However, ideal participation is the active involvement of the people in making the decisions about programmes and the designing of the programmes. De Beer \& Swannepoel (1998) advocate for the kind of participation whereby people participate during all stages of its programmes from designing, implementation to evaluation as this virtually ensures the programme's success.

In terms of involvement during designing, implementation and evaluation of projects, two thirds of the 111 
respondents reported that they were involved in the designing of programmes with GAA. Out of all the respondents, 104 reported that they did projects on their own. Just more than three quarters of the respondents reported that they could do projects without GAA personnel and just more than half (55.9\%) reported that they evaluated projects on their own.

There was a significant association (Chi-square $=5.946, p$-value $=.015$ ) between involvement in designing of programmes with GAA and gender with females likely to report that they were more involved than males in designing of programmes with GAA.

Highly significant associations were also observed between own evaluation of projects and how long respondents had known GAA (Chi-square=38.656, p-value=.000), number of dependants (Chi-square $=25.484$, p-value $=.000$ ) and gender (Chi-square=7.694, p-value=.000). People who have known GAA for only up to 4 years are likely to agree that they were evaluating projects on their own while people with more than four dependants were unlikely to be agreeable to do their own project evaluation and females were likely to report own evaluation of projects.

\subsection{Effectiveness of the GAA's communication on poverty alleviation in Gokwe South Rural District}

GAA has tried to make use of what is at its disposal in terms of the mediums of communication which it could use. The communication has been effective considering the growth in the number of partners. The indigenous communication systems have worked well unlike the modern communication systems. The organisation only makes a little use of print media in form of posters, leaflets and letters. It also made use of the cell phone and has an unofficial website at district level.

Although vilified in the alternative paradigm of development communication (Melkote, 2001), MCSs facilitate the fast flow of information (Fourie, 2001). GAA has however failed to use radio, TV, newspapers or magazines for communication. Instead, it mainly used meetings and face-to-face which are indigenous forms of communication. This is not to suggest that indigenous forms of communication should not be used but that they should be integrated with the modern communication systems. This is rather impossible in Zimbabwe because of the restrictive media laws. The broadcasting and publishing fraternity is restricted by the Broadcasting Services Act of 2001 which resulted in the formation of the Broadcasting Authority of Zimbabwe (BAZ). This body regulates the registration in the broadcasting industry. It has however been blamed for being used as a state tool to advance the idea of monopolising the media (MISA). As a result of this, there is only one national television station and four national radio stations. These are not close to the locals and the NGOs cannot use them for purposes of development communication. There are no community radio stations in Zimbabwe. These have a great potential being used for communication so as to bring about poverty alleviation.

Considering the educational levels, the communication methods used were ideal, especially the ICSs coupled the MCSs although the latter were used to a lesser extent. When the educational levels of the respondents were collapsed into only two categories, "Form 2 (at this level of education most people in Zimbabwe can read and write at least one first language and English) and below" and "beyond Form 2", a highly significant association between gender and educational level was observed. Females in the population where the data were collected had attended school up to Form 2 only while males were likely to have gone beyond Form 2. Risk analysis results showed that females were ten times more likely to have gone up to Form 2 while males up to tertiary level $[\mathrm{OR}=.100,95 \% \mathrm{Cl}=(.040, .250)]$. The implementation of the MCSs to lesser extent was noted as a concern since the population was likely to use and get messages well from the modern communication systems if GAA used them.

The limitations in the use of print media such as newspapers and magazines are also a result of restrictive laws. The Access to Information and Privacy Protection Act (AIPPA) has resulted in the closure of newspaper agents and the arrest of many journalists in Zimbabwe. The implication of this act on the communication activities by any NGO has been twofold; it limits the number of newspaper agents which the organisation can use to communicate with the locals and also causes the organisation to fear communicating with the people using print media. The organisations and anyone intending to communicate via print media would do a thorough self censorship before doing that so as to avoid breaching the AIPPA.

The people in the district are educated to an extent that they can interact with the organisation through print. The organisation could either use leaflets, posters and magazines to inform people mainly about the proposed projects as well as how the people can do the projects on their own. Information providing answers to questions could also be shared in this manner. 


\section{Summary of Findings}

1. The organisation used mainly ICSs. Meetings and interpersonal communication were the main features in the GAA communication practices. The use of names as form communication was also noted but to a lesser extent. MCSs were used but to a lesser extent. This was in form of the unofficial website, cell phones and letters. The organised used mainly indigenous languages for communication. These are Shona and Ndebele. English was also used. The organisation was flexible with the use of the language and the people in Gokwe understood the messages.

2. The issues in GAA's messages were on poverty alleviation. By meetings, GAA informed, educated and encouraged the people of Gokwe on its programmes of poverty alleviation. These were on crop production using Conservative Farming (CF), livestock production projects, health and nutrition through the Nutritional Gardening (NG) projects and food and sustainability through the granaries project. GAA also dealt with water and sanitation in its communication activities. Family planning issues were also addressed as reported by $20.7 \%$ of the questionnaire respondents. All these issues were in GAA's messages. Communication was mainly centred on the organisation's key result areas.

3. The study found out that the locals were involved in the communication activities of the organisation. There were Field Technicians (FTs) and Lead Farmers (LFs). They were actively involved in the communication activities, face-to-face or meetings. During events, locals also participated though drama, music and dance. With these, they encouraged other people to participate in GAA projects and to work hard to conquer poverty. This facilitated the diffusion on innovations and encouraged their adoption in Gokwe.

The feedback system was effective when considering the ICSs but there were no much mass media platforms. People could communicate with organisations through the FTs and LFs who lived among them. People could also communicate with the organisation during meetings and a few can make use of the cell phone. The unavailability of a variety of channels rendered the feedback system less effective.

4. GAA's communication on poverty alleviation in Gokwe has been partially effective. The organisation made use of the available communication systems which were mainly indigenous. Due to various limitations beyond the organisation's control, which are poor infrastructure, political factors and the limited and state monopolised print and broadcast media, the organisation failed to make use of the MCSs for poverty alleviation programmes. Most of the people had known GAA for more than 4 years. This means that there were no knew adopters. The organisation was not growing continued to work with the same people without new adopters. Communication was not effectively used to influence new people to join the organisation. There was no organisation directorate directly responsible for the communication activities in terms of research, implementation and evaluation at district level. As a result, the organisation did not have a clear communication strategy.

\section{Recommendations}

1. Tilled Communication Field Approach. After having analysed the data, it was clear that much is needed to be done to make the ground of communication ready for use by everyone in the district, NGOs included. As a result, the researcher suggested a Tilled Communication Field proposal. By this, the government, locals, NGOs and the international community are invited to till the ground of communication so that all modes of communication can be easily used in the rural community for poverty alleviation and to empower the rural folk. This entails ensuring that traditional communication can be integrated with modern communication approaches for poverty alleviation.

The Tilled Communication Approach will help offer channels to be used either by change agents or the locals to share information or for mobilisation. This also involves an investment into the infrastructure in terms of electricity supply, network boosters and an improved road network. There is also need by the government to open up the airwaves for community broadcasting which will be relevant to the rural communities. The government must also relax its rules regarding community media like radio, magazines and newspapers. The availability of these will facilitate the integration of traditional forms of communication with the modern forms of media for poverty alleviation in rural areas. This has the potential of facilitating the diffusion of innovations and encouraging participation which is necessary for poverty alleviation. Unless this is done, realising the communications' capabilities in social change and development will remain a dream never to come true in 
Zimbabwe and most specifically, Gokwe South Rural District.

2. The results of this study revealed that the communication practices of GAA were mainly limited to meetings and interpersonal face-to-face. However, there is need for a broader approach by GAA to exhaust a variety of communication modes and integrate them with modern communication systems to reach to a widely dispersed audience and open channels for their effective participation. This will empower the locals to voice out their concerns by furnishing them with all the necessary information concerning poverty alleviation. By so doing, the challenge of complacency will be defeated (Serveas, 2008, De Beers and Swannepoel, 1998). It is however recommended that GAA opens more platforms for participatory development communication and well as uses the platforms to empower the locals with the necessary information.

3. The research found that the use of the local language has been effective in GAA's communication with the locals. It is therefore recommended that GAA continues to use all local languages in both verbal and written communications so that information continues to get to the locals. The use of all languages Shona, Ndebele and Tonga in all printed documents be it leaflets or posters will give everyone an opportunity to read and participate in the conversations which in turn encourage participation in the poverty alleviation programmes. Print media in form of leaflets is permanent. It can be shared and used by others at different times.

4. As any organisation operating at district level, this paper recommends that GAA should have dedicated personnel to address communication issues. These should work together with the FOs, FTs and LFs and ascertain that there is an effective flow of information in both ICSs and MCSs. There will also be clear communication strategies involving communication.

5. People who decide to use communication mediums for any form of communication need to consider whether what they are using the media for is for the benefit of the society at large or not. By this, the research does not suggest to do away with communications regulations but regulations which promote rather than hinder.

6. Finally, the research recommends that the rural folks be enabled to participate in the communication activities from the designing, implementation to the evaluation of poverty alleviation programmes (Serveas, 2008).

\section{Conclusion}

This paper presented findings from a study which employed both quantitative and qualitative approaches. Data gathering involved the use of a questionnaire and interviews. Based on the findings, the organisation used ICSs mainly in form of meetings and face-to-face interpersonal communication. The MCSs were not exhaustively used and usage was reflected in the use of cell phones, letters, leaflets and posters. Horizontal communication was mainly reflected through the use of MCSs and top down communication as well as bottom up communication manifested through the use of ICSs.

Interpersonal face-to-face communication and meetings were used for information sharing, public discussions and awareness of GAA as well as the programmes conducted. The issues that the organisation dealt with were mainly concerned with poverty alleviation. However, the communication strategies including both indigenous and modern modes of communication must be exhaustively used and integrated to address the issues of poverty alleviation. GAA has failed to approach its communication in a multidimensional manner.

The discovery is that there were infrastructural, economic, legal or constitutional and political challenges which inhibited a multidimensional approach to communication. The research therefore suggested the Tilled Communication Field approach for Zimbabwe so as to open channels for development and social change agents which will assist in ending poverty in the district and the nation at large.

The use of multiple communication systems that are both indigenous and modern facilitate the diffusion of innovations by allowing the locals to fully participate in the development projects meant for their own development. Participatory development communication which is a form of communication that invites dialogue of the masses at the grassroots can be enhanced by the use of MCSs and ICSs and most importantly, their integration.

Also of much importance was the GAA's communication with its stakeholders. It facilitated the organisational operations and allowed for the sharing of ideas. The horizontal communication approach involving using telephone and letters by GAA with its stakeholders is appreciated. The organisation does not operate in isolation and in this regard communication was effectively used. 


\section{References}

Anyaegbunam, C, Mefalopulos, P and Moetsabi (2004) Participatory Communication Appraisal: Staring with the people: A handbook $2^{\text {nd }}$ Ed. Rome. FAO.

Creswell, J. W. (1999). Mixed-method research: Introduction and application. In G. Cizek (Ed.), Handbook of educational policy. San Diego, CA: Academic Press.

Creswell, J. W. (2003). Research design: Qualitative, quantitative, and mixed methods approaches (2nd ed.). Thousand Oaks, CA: Sage.

Currie, D (2005). Developing and Applying study skills: Writing Assignments and Management Reports. London: Chartered Institute of Personnel Development.

De Beer, F \& Swannepoel, H. (1998). Community Development and Beyond: Issues, structures and procedures. Pretoria. JL van Schaik

FAO (2000). Communication: A key to human development. FAO. Retrieved from www.fao.org on 27/11/2012.

FAO, (2012). Communication for Development retrieved from www.fao.org on 25/06/2012

Fourie, P.J. (2001). Media Studies: Content, Audience and Production. Volume 2. Cape Town: Juta.

Grix, J (2001). Demystifying Postgraduate Research: From MA to PhD. UK: University of Birmingham Press.

Hughes, C (1997) Mystifying through coalescence: The underlying politics of methodological choices, in K Watson, C Modgil and S Modgil (Eds) Educational Dilemmas: Debate and Diversity, Quality in Education, London, Cassell, pp 413-420.

James, N (2006) 'Factors affecting the sustainability of Cotton Production: Changing Rural Livelihood in the North West Region in Zimbabwe'. Retrieved from www.academic.edu on 25/06/2011

Korten, D. (1986) Micro-Policy Reform: The Role of Private Voluntary Agencies. NASPAA Working Paper No. 12 (Washington).

Manyozo, L.P (2008) Communication for Development An Historical Overview ( $p$ 31-53): Reports prepared for UNESCO on the occasion of the International Association of Media and Communication Research (IAMCR) $50^{\text {th }}$ Anniversary Conference; Media, Communication and Information Celebrating 50 years of Theory and Practice: UNESCO. Paris

McQuail, D. 2010. McQuail's Mass Communication Theory $6^{\text {th }}$ Ed. London. Sage.

Melkote, S (2001). Communication for Development in the Third World: Theory and Practice for empowerment. Thousand Oaks: Sage.

Mozammel, M. and Odugbemi, S. (eds.). 2005. With the Support of Multitudes, Using Strategic Communication to fight Poverty through PRSPS. Information and Communication for Development, United Kingdom Department for International Development, and the Development Communication Division, External Affairs. World Bank. Retrieved on http://siteresources.worldbank.org on 26/11/2011.

Nenty, H.J (2009). Writing a Quantitative Research Thesis. International Journal for Educational Sciences 1 (1) 19-31

Ranger, T. (1985). Consciousness and Guerrilla War in Zimbabwe. James Currey, Oxford

Rogers, E.M. (2005). Diffusion of innovations (6th ed.). New York: The Free Press.

Salawu, A. (2004a). 'A foundational paradigm of development and development communication in Africa'. Journal of Society, Development and Public Health, Vol. 1, pp.57-71.

Salawu, A. (2004b). 'The intrinsic value of Oramedia for development'. Humanities Review Journal, Vol. 4. A New Approach to Development: Humanities Research Forum. Ibadan Nigeria

Salawu, A. (2004c). A determination of the use of indigenous language newspapers by development agencies Vol v (2004) Pp. 1-19 Unilag Sociological Review (USR). Lagos, Nigeria

Serveas, J (Ed.). 2008. Communication for Development and Social Change. SAGE. Los Angeles.

Strauss, A. \& Corbin, J. (1990). Basics of qualitative research: Grounded theory procedures and techniques. Newbury Park: Sage Publications, Inc.

Strauss, A., \& Corbin, J. (1998). Basics of qualitative research: Techniques and procedures for developing grounded theory (2nd ed.). Thousand Oaks, CA: Sage.

Tashakkori, A. and Teddlie, C. (1998). Mixed methodology: Combining qualitative and quantitative approaches. Thousand Oaks, CA; Sage.

UNESCO (2012). Why Language Matters for the Millennium Development Goals. Thailand UNESCO.

Worby, E (2000) 'Discipline without oppression: sequence, timing and marginality in Southern Rhodesia's post war development regime.Journal of African History 41, 101-125 
